\title{
SERUM POTASSIUM, MAGNESIUM, AND CALCIUM LEVELS IN DIABETIC ACIDOSIS
}

\author{
By HELEN EASTMAN MARTIN AND MAXINE WERTMAN \\ (From the Department of Medicine of the University of Southern California School of \\ Medicine, and the Los Angeles County Hospital)
}

(Received for publication August 21, 1946)

A study of changes in serum potassium, magnesium, and calcium levels during therapy for severe diabetic acidosis seemed indicated in view of the fact that the majority of previous reports $(1,2,3)$ have dealt primarily with sodium levels or total base, with little detailed study of the other bases. The articles of Harrop (4) and Atchley (5) are exceptions, and include a few determinations of serum potassium and calcium in two patients each. ${ }^{1}$ It was hoped also that this study would throw light on some of the unexplained symptoms and signs which occur during and following therapy for diabetic acidosis.

\section{MATERIAL}

Fourteen patients, ranging from ages $12-69$, who entered the hospital in severe diabetic acidosis (carbon-dioxide combining power expressed as milliequivalents of bicarbonate, under 9 milliequivalents) were studied. All of these patients survived with the exception of a 56-year-old woman who died within 30 hours, with unexplained hyperpyrexia and morbilliform rash. Post-mortem examination did not contribute to the solution of the problem, although virus studies are not yet completed. Serial determinations of serum potassium, sodium, calcium, magnesium, and total protein were made on all patients, in addition to the usual determinations of blood sugar, carbon-dioxide combining power, and non-protein nitrogen. In seven of the patients $\mathrm{pH}$, and albumin and globulin fractions were also determined. Phosphorus levels determined as inorganic phosphate were run on two patients.

\section{METHODS}

The $\mathrm{pH}$ was determined on venous blood by the use of the Beckman $\mathrm{pH}$ meter, serum sodium by a modification of the zinc uranyl acetate method of Barber and Kolthoff

\footnotetext{
1 Since the preparation of this manuscript a report of 1 patient in diabetic acidosis who developed low potassium levels (2.5 milliequivalents) during therapy, which were associated with respiratory paralysis, and which responded to potassium intravenously, has appeared. Holler, Jacob W., Potassium deficiency occurring during the treatment of diabetic acidosis. J. A. M. A., 1946, 13, 1186.
}

(6), potassium by the Kramer and Tisdall (7) cobaltinitrate method, calcium by the Clark and Collip (8) modification of the Tisdall method, and magnesium and inorganic phosphorus by methods from this laboratory ( 9 , 10). Albumin and globulin fractions and total protein were performed by the method of Kingsley (11), the carbon-dioxide combining power by the Van Slyke (12) method, and, calculated as M.eq. of bicarbonate, nonprotein nitrogen by the method of Peters and Van Slyke (13) and blood sugar by the method of Benedict (14).

Ionized calcium was calculated from the mass action law :

$\frac{\left(\mathrm{Ca}^{++}\right)(\text {Proteinate }=)}{\text { (Calcium Proteinate) }}=10^{-2.22}$

$(\mathrm{pK}$ Calcium Proteinate $=2.2) \quad(15)$.

Total protein was converted to grams per 1000 grams $\mathrm{H}_{2} \mathrm{O}$ by the formula :

grams water per $100 \mathrm{ml}=99-0.75$

$$
\times \text { protein (grams per } 100 \mathrm{ml} \text { ) }
$$

and albumin and globulin fractions corrected accordingly.

The base combining capacity of the albumin and globulin were calculated at each $\mathrm{pH}$, using the values of Van Slyke, et al. (17).

M.eq. Base per grams albumin $=0.125(\mathrm{pH}-5.16)$.

M.eq. Base per grams globulin $=0.077(\mathrm{pH}-4.89)$.

\section{RESULTS}

Table I shows the changes in electrolytes, blood sugar, carbon-dioxide combining power, and nonprotein nitrogen, correlated with treatment (amount of insulin, fluids, sodium, and glucose), and with the clinical state.

Certain general features appear from inspection of this table:

1. The marked acidosis, and hemoconcentration on entry. The total protein concentration was used as a gauge of hemoconcentration.

2. The fall in serum potassium concentration during therapy. In some patients the values reached critically low levels-1.9 and 2.18 M.eq. 
TABLE I

Correlation of chemistry, treatment and clinical state

No. 1, Patient T. B., Colored Female, 19, No. 683-113

\begin{tabular}{|c|c|c|c|c|c|c|c|c|c|c|c|c|c|c|c|c|c|c|c|}
\hline \multicolumn{2}{|c|}{ Time } & \multicolumn{11}{|c|}{ Blood chemistry } & \multirow{2}{*}{\multicolumn{6}{|c|}{$\begin{array}{c}\text { Treatment } \\
\begin{array}{c}\text { Therapy between hrs. listed, with } \\
24 \text { hr. summary }(\mathbf{d})\end{array}\end{array}$}} & \multirow{3}{*}{$\begin{array}{c}\text { Clinical } \\
\text { state }\end{array}$} \\
\hline \multirow{3}{*}{ Day } & \multirow{3}{*}{ Hr. } & & \multirow{2}{*}{$\mathbf{K}$} & \multirow{2}{*}{$\mathrm{Na}$} & \multirow{2}{*}{$\mathrm{Ca}$} & \multirow{2}{*}{$\mathbf{M g}$} & \multicolumn{3}{|c|}{ Serum protein } & \multirow{2}{*}{ Sugar } & \multirow{2}{*}{$\mathrm{HCO}_{2}-$} & \multirow{2}{*}{ NPN } & & & & & & & \\
\hline & & & & & & & Alb. & Glob. & Total & & & & N.S.(2) & $\left|\begin{array}{l}\mathrm{M} / 6 \mathrm{Na} \\
\text { lactate }\end{array}\right|$ & \multicolumn{2}{|c|}{$5 \%$ glucose in } & \multirow{2}{*}{$\begin{array}{l}\text { Plasma } \\
\text { liters }\end{array}$} & \multirow{2}{*}{ Insulin } & \\
\hline & & $p H$ & meq. & meq. & meq. & meq. & $\begin{array}{c}\text { grams } \\
\text { per } \\
\text { cent }\end{array}$ & $\mid \begin{array}{c}\text { grams } \\
\text { per } \\
\text { cent }\end{array}$ & $\begin{array}{c}\text { grams } \\
\text { per } \\
\text { cent }\end{array}$ & $\begin{array}{c}\text { mgmm. } \\
\text { per } \\
\text { cent }\end{array}$ & meq. & $\begin{array}{c}\underset{\text { gem }}{\text { per }} \\
\text { cent }\end{array}$ & liters & liters & $N . S_{i_{i}}$ & $\underset{\mathrm{Hers}}{\mathrm{H}_{2} \mathrm{O}}$ & & & \\
\hline \multirow[t]{5}{*}{1} & $\mathbf{0}$ & 7.05 & 6.72 & 152 & 5.25 & 1.98 & 5.9 & 3.4 & 9.7 & 545 & 7.5 & & & & & & & & \\
\hline & 6 & 7.29 & 5.42 & 161 & 4.65 & 1.16 & 4.7 & 2.6 & 7.3 & 230 & 9.5 & & 2 & & 1 & & & 110 & Conscious \\
\hline & 21 & & & & & & & & & 117 & 22.0 & & & 2 & & (i0\%) & & 90 & \\
\hline & 24 & & & & & & & & & & & & & & & & & 30 & \\
\hline & & & & . & & & & & & & & & \multicolumn{6}{|c|}{$\begin{array}{l}5,650 \text { ml. fluids; } 18.3 \text { grams } \mathrm{Na} \\
115 \text { grams glucose; } 230 \text { units insulin }\end{array}$} & \\
\hline 2 & & 7.55 & 3.20 & 158 & 4.80 & 0.56 & 3.9 & 2.0 & 5.9 & & & & & & & & & 80 & $\begin{array}{r}\text { Muscle } \\
\text { aches }\end{array}$ \\
\hline 3 & & 7.55 & 4.56 & 160 & 4.70 & 1.40 & 3.6 & 1.9 & 5.5 & & & & & & & & & 60 & \\
\hline 4 & & 7.58 & 4.56 & 160 & 5.00 & 1.48 & 4.1 & 2.1 & 6.2 & & & & & & & & & 60 & \\
\hline
\end{tabular}

No. 2, Patient A. B., White Male, 69, No. 723-522

\begin{tabular}{|c|c|c|c|c|c|c|c|c|c|c|c|c|c|c|c|c|c|}
\hline \multirow[t]{5}{*}{1} & 0 & & & & & & & & & 618 & 8.0 & 65 & & & & & \\
\hline & 2 & 7.28 & 5.38 & 138 & 4.35 & 1.47 & 3.5 & 2.3 & 5.8 & 452 & 10.0 & 48 & 1 & & & 80 . & Conscious \\
\hline & 20 & 7.60 & 1.90 & 142 & 4.30 & 1.06 & 3.1 & 1.8 & 4.9 & 97 & 24.0 & & G1.(4) & 1 & 2 & 225 & \\
\hline & 24 & & & & & & & & & & & & & & & 15 & \\
\hline & & & & & & & & & & & & & \multicolumn{4}{|c|}{$\begin{array}{l}5,350 \mathrm{ml} \text {. fluids; } 11.8 \text { grams } \mathrm{Na} ; \\
175 \text { grams glucose; } 320 \text { units insulin }\end{array}$} & \\
\hline 2 & 1 & 7.65 & 2.77 & 142 & 4.40 & 1.39 & 3.0 & 1.9 & 4.9 & & & & & & & 35 & $\begin{array}{l}\text { Marked } \\
\text { weakness }\end{array}$ \\
\hline & 20 & 7.63 & 2.18 & 152 & 4.30 & 1.47 & 3.1 & 1.9 & 5.0 & & & & & & & & \\
\hline 3 & & 7.59 & 3.36 & 153 & 4.25 & 1.39 & 3.0 & 1.9 & 4.9 & & & & & & & 20 & \\
\hline 4 & & 7.60 & 5.13 & 151 & 4.45 & 1.56 & 3.1 & 2.1 & 5.2 & & & & & & & 30 & \\
\hline 5 & & 7.57 & 6.64 & 145 & 4.40 & 1.23 & 2.8 & 1.8 & 4.6 & & & & & & & 30 & \\
\hline 6 & & 7.52 & 4.31 & 156 & 4.75 & 1.31 & 3.5 & 2.2 & 5.7 & & & & & & & 60 & \\
\hline 7 & & 7.55 & 6.13 & 146 & 4.50 & 1.39 & 3.2 & 1.9 & 5.1 & & & & & & & 60 & \\
\hline
\end{tabular}

No. 3, Patient H. C., White Female, 56, No. 964-879

\begin{tabular}{|c|c|c|c|c|c|c|c|c|c|c|c|c|c|c|c|c|c|c|}
\hline \multirow[t]{3}{*}{1} & 2 & 7.10 & & 147 & 4.90 & 2.75 & 5.1 & 2.9 & 8.0 & 830 & $<4.5$ & 38 & & & & & & \multirow{2}{*}{$\begin{array}{l}\text { Deeply. } \\
\text { comatose; } \\
\text { shock }\end{array}$} \\
\hline & 23 & 7.22 & 4.32 & 163 & 5.30 & 1.83 & 4.4 & 2.4 & 6.8 & 204 & 19.0 & 45 & 2 & 1 & 3 & 1 & 205 & \\
\hline & & & & & & & & & & & & & \multicolumn{5}{|c|}{$\begin{array}{l}7.000 \text { ml. fluids; } 21.5 \text { grams } \mathrm{Na} ; \\
150 \text { grams glucose; } 205 \text { units insulin }\end{array}$} & Death \\
\hline
\end{tabular}

(1) Includes only intravenous fluids given between the hours listed.

(2) Isotonic saline.

(3) Insulin in first 24 hours was crystalline zinc insulin given in divided doses every 1-3 hours. On remaining days total includes crystalline zinc and protamine zinc insulin.

(4) $50 \mathrm{ml} .50$ per cent glucose in water. 
TABLE I-Continued

No. 4, Patient E. S., White Female, 19, No. 962-393

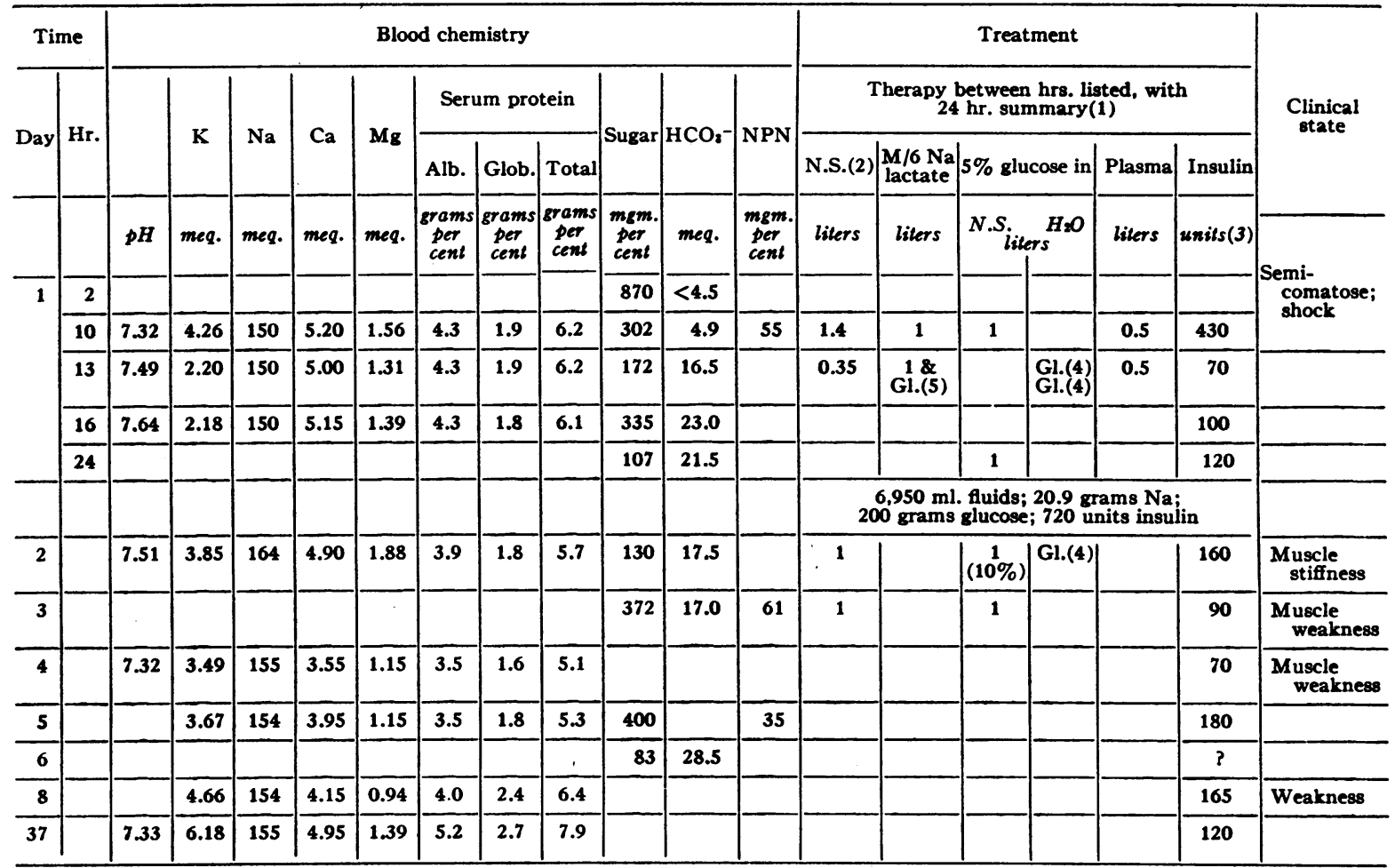

No. 5, Patient B. M., White Male, 19, No. 968-418

\begin{tabular}{|c|c|c|c|c|c|c|c|c|c|c|c|c|c|c|c|c|}
\hline \multirow[t]{5}{*}{1} & 2 & 7.12 & 7.28 & 174 & 5.70 & 2.13 & 6.8 & 3.0 & 9.8 & 575 & 7.0 & & & & & Conscious \\
\hline & 5 & 7.45 & 5.46 & 165 & 5.10 & 1.72 & 5.7 & 2.4 & 8.1 & 215 & 10.0 & 1 & $\begin{array}{c}1 \\
1 \& \\
\text { Gl.(6) }\end{array}$ & & 105 & \\
\hline & 9 & 7.51 & 5.00 & 159 & 4.65 & 1.56 & 4.5 & 1.9 & 6.4 & 227 & 18.5 & - & & 1 & 40 & \\
\hline & 15 & & & 144 & 4.40 & 1.80 & 4.1 & 1.8 & 5.9 & 84 & 23.5 & & & 2 & 30 & \\
\hline & 24 & & & & & & & & & & & & & & $\mathbf{0}$ & \\
\hline & & & & & & & & & & & & \multicolumn{4}{|c|}{$\begin{array}{l}6,150 \text { ml. fluids; } 21.8 \text { grams } \mathrm{Na} ; \\
225 \text { grams glucose; } 175 \text { units insulin }\end{array}$} & \\
\hline 2 & & 7.58 & 5.74 & 140 & 4.40 & 1.23 & 4.1 & 1.8 & 5.9 & & & & & & 100 & \\
\hline 5 & & 7.51 & 5.64 & 142 & 4.85 & 1.47 & 4.4 & 2.1 & 6.5 & 252 & 26.0 & & & & 90 & \\
\hline
\end{tabular}

No. 6, Patient N. W., White Female, 44, No. 319-307

\begin{tabular}{|c|c|c|c|c|c|c|c|c|c|c|c|c|c|c|c|c|c|}
\hline \multirow[t]{4}{*}{1} & 0 & & 8.72 & 133 & 4.95 & 1.88 & 4.7 & 3.2 & 7.9 & 683 & $<4.5$ & & & & & & Conscious \\
\hline & 20 & 7.58 & 3.41 & 141 & 3.85 & 0.82 & 3.1 & 2.0 & 5.1 & 178 & 17.0 & $2(8)$ & 1.3 & 1 & 1 & 110 & \\
\hline & 24 & & & & & & & & & & & & & & & 0 & \\
\hline & & & & & & & & & & & & \multicolumn{5}{|c|}{$\begin{array}{l}7,300 \mathrm{ml} \text {. fluids; } 22.7 \text { grams } \mathrm{Na} ; \\
100 \text { grams glucose; } 110 \text { units insulin }\end{array}$} & \\
\hline \multirow[t]{2}{*}{2} & 1 & 7.65 & 7.61 & 139 & 4.00 & 1.23 & 3.0 & 1.8 & 4.8 & & & & & & & 25 & \\
\hline & 23 & 7.60 & & 135 & 4.05 & 1.23 & 3.1 & 2.0 & 5.1 & & & & & & & & \\
\hline 5 & & 7.56 & 5.64 & 153 & 4.50 & 1.47 & 3.9 & 2.3 & 6.2 & & & & & & & 35 & \\
\hline 7 & & 7.38 & 6.14 & 153 & 3.95 & 1.31 & 3.5 & 2.2 & 5.7 & $\begin{array}{l}\mathbf{3 7 0} \\
\mathbf{5 7 0} \\
\mathbf{3 3 0}\end{array}$ & $\begin{array}{r}7.5 \\
11.5 \\
17.5\end{array}$ & & & & & 95 & \\
\hline 8 & & & 5.28 & 153 & 4.15 & 1.31 & 3.4 & 2.2 & 5.6 & & & & & & & 60 & \\
\hline 11 & & & 4.59 & 153 & 4.55 & 1.56 & 3.7 & 2.3 & 6.0 & & & & & & & 40 & \\
\hline
\end{tabular}

(5) $100 \mathrm{ml}$. 50 per cent glucose in water added to the $1 / 6 \mathrm{M}$ sodium lactate.

(6) $150 \mathrm{ml}$. 50 per cent glucose in water added to the $1 / 6 \mathrm{M}$ sodium lactate. 
TABLE I-Continued

No. 7, Patient T. A., White Male, 17, No. 34-034

\begin{tabular}{|c|c|c|c|c|c|c|c|c|c|c|c|c|c|c|c|c|c|}
\hline \multirow{3}{*}{ Day } & \multirow{3}{*}{ Hr. } & \multicolumn{10}{|c|}{ Blood chemistry } & \multirow{2}{*}{\multicolumn{5}{|c|}{ 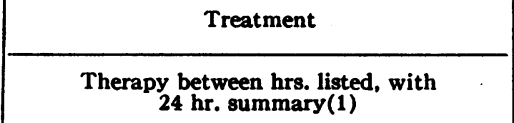 }} & \multirow{3}{*}{$\begin{array}{l}\text { Clinical } \\
\text { state }\end{array}$} \\
\hline & & \multirow{2}{*}{$\mathbf{K}$} & \multirow{2}{*}{$\mathbf{N a}$} & \multirow{2}{*}{$\mathrm{Ca}$} & \multirow{2}{*}{$\mathbf{M g}$} & \multicolumn{3}{|c|}{ Serum protein } & \multirow[b]{2}{*}{ Sugar } & \multirow{2}{*}{$\mathrm{HCO}_{2}-$} & \multirow{2}{*}{ NPN } & & & & & & \\
\hline & & & & & & Alb. & Glob. & Total & & & & N.S.(2) & $\begin{array}{l}\mathrm{M} / 6 \mathrm{Na} \\
\text { lactate }\end{array}$ & $5 \%$ glucose in & Plasma & Insulin & \\
\hline & & meq. & meq. & meq. & meq. & $\begin{array}{l}\text { grams } \\
\text { per } \\
\text { cent }\end{array}$ & $\begin{array}{c}\text { grams } \\
\text { per } \\
\text { cent }\end{array}$ & $\begin{array}{c}\text { grams } \\
\text { per } \\
\text { cent }\end{array}$ & $\begin{array}{c}\text { mgm. } \\
\text { per } \\
\text { cent }\end{array}$ & meq. & $\begin{array}{l}\text { mgm. } \\
\text { per } \\
\text { cent }\end{array}$ & liters & liters & N.S. iiters $^{\mathrm{H}_{2} \mathrm{O}}$ & liters & units (3) & \\
\hline \multirow[t]{6}{*}{1} & $\mathbf{0}$ & 6.00 & 148 & 4.90 & 2.33 & 5.2 & 3.1 & 8.3 & 375 & $<4.5$ & 37 & & & & & & comatose \\
\hline & 4 & 5.57 & 148 & 4.15 & 1.83 & 4.3 & 2.4 & 6.7 & 235 & 6.5 & & 2 & & 1 & & 120 & \\
\hline & 8 & & & & & & , & & 180 & 21.0 & & & & & & & \\
\hline & 16 & & 161 & 4.25 & 1.83 & 3.7 & 2.2 & 5.9 & 119 & & & & 1 & 1 & & 90 & \\
\hline & 24 & & & & & & & & & & & & & & & 15 & \\
\hline & & & & & & & & & & & & \multicolumn{5}{|c|}{$\begin{array}{l}5,000 \text { ml. fluids; } 18 \text { grams } \mathrm{Na} ; \\
100 \text { grams glucose; } 225 \text { units insulin }\end{array}$} & \\
\hline 2 & & 4.36 & 154 & 4.00 & 0.98 & 3.2 & 1.6 & 4.8 & & & & & & & & $60 ?$ & \\
\hline 3 & & 5.93 & 159 & 4.40 & 1.23 & 3.5 & 2.0 & 5.5 & & & & & & & & $60 ?$ & \\
\hline
\end{tabular}

No. 8, Patient A. D., White Female, 39, No. 954-618

\begin{tabular}{|c|c|c|c|c|c|c|c|c|c|c|c|c|c|c|c|}
\hline 1 & 0 & & & & & & 285 & 6.5 & & & & & & & \multirow[b]{2}{*}{ Conscious } \\
\hline & 3 & 4.26 & 151 & 4.40 & 1.11 & 7.9 & 352 & 12.5 & 1 & Gl.(5) & & & & 80 & \\
\hline & 15 & & & & & & 192 & 23.5 & & Gl. 18 & 2 & 3 & & 275 & \\
\hline & 24 & & & & & & & & & & & & 0.5 & 40 & \\
\hline & & & & & & & & & \multicolumn{6}{|c|}{$\begin{array}{l}8.700 \mathrm{ml} \text {. fluids; } 18.3 \text { grams Nar } \\
350 \text { grams glucose; } 395 \text { units insulin }\end{array}$} & \\
\hline 2 & & 7.21 & 151 & 4.55 & 1.31 & 5.8 & & & & & & & & 30 & \\
\hline
\end{tabular}

No. 9, Patient M. K., White Male, 16, No. 947-988

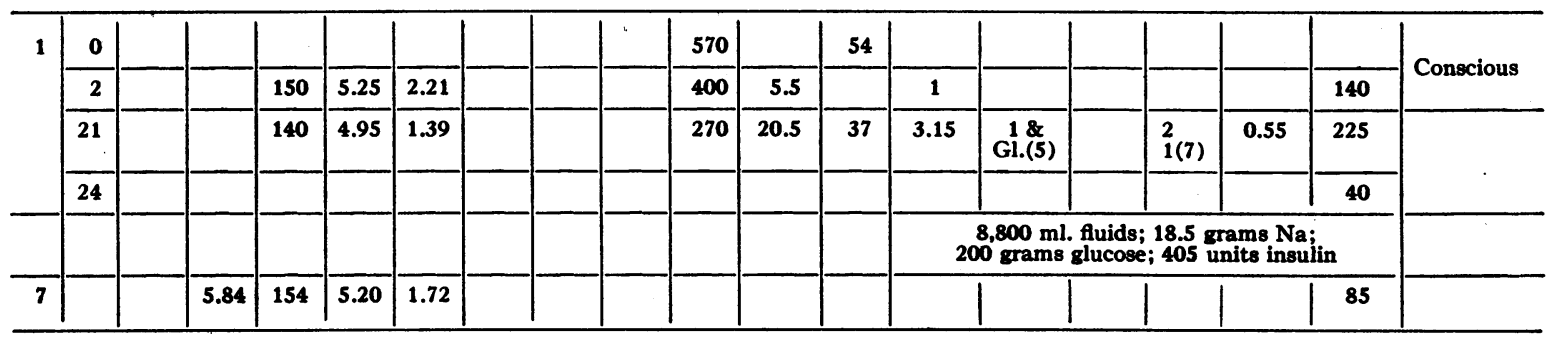

No. 10, Patient F. C., White Male, 12, No. 211-641

\begin{tabular}{|c|c|c|c|c|c|c|c|c|c|c|c|c|c|c|c|c|}
\hline \multirow[t]{4}{*}{1} & O & & & & & & 1,092 & $<4.5$ & & & & & & & & \multirow{2}{*}{$\begin{array}{l}\text { Deeply } \\
\text { comatose; } \\
\text { shock }\end{array}$} \\
\hline & 3 & & 141 & 5.25 & 2.46 & 7.2 & 810 & 9 & 121 & 0.6 & 0.15 & & & 0.5 & 200 & \\
\hline & 6 & & 141 & $5.75^{\circ}$ & 2.87 & 7.2 & 487 & 18.5 & 150 & & 0.5 & & & 0.25 & 90 & \\
\hline & 24 & & & & & & & & & 1 & & 0.65 & 0.13 & & 185 & \\
\hline & & & & & & & & & & \multicolumn{6}{|c|}{$\begin{array}{l}3,780 \text { ml. fluids; } 10.5 \text { grams Na; } \\
39 \text { grams glucose; } 475 \text { units insulin }\end{array}$} & \\
\hline 2 & & & & & & & 98 & 16.5 & & 1 & & 0.60 & 0.67 & & 70 & \\
\hline 3 & & & & & & & 219 & 18.5 & & 0.3 & & 1 & 2.80 & . & 55 & \\
\hline 4 & & 4.87 & 136 & 4.45 & 1.56 & 5.6 & 282 & 8.0 & 129 & & & 1 & 1 & & 50 & \\
\hline 5 & & 8.15 & 146 & 4.30 & 2.04 & 5.2 & 476 & 19.0 & 99 & & & 1 & 1 & & 120 & \\
\hline
\end{tabular}

(7) $2 \frac{1}{2}$ per cent glucose in water given subcutaneously. 
TABLE I-Continued

No. 10, Patient F. C., White Male, 12, No. 211-641-(continued)

\begin{tabular}{|c|c|c|c|c|c|c|c|c|c|c|c|c|c|c|c|c|c|c|c|}
\hline \multicolumn{2}{|c|}{ Time } & \multicolumn{11}{|c|}{ Blood chemistry } & \multicolumn{6}{|c|}{ Treatment } & \multirow{3}{*}{$\begin{array}{c}\text { Clinical } \\
\text { state }\end{array}$} \\
\hline \multirow{3}{*}{ Day } & \multirow{3}{*}{ Hr. } & & \multirow{2}{*}{$\mathbf{K}$} & \multirow{2}{*}{$\mathbf{N a}$} & \multirow{2}{*}{$\mathrm{Ca}$} & \multirow{2}{*}{$\mathbf{M g}$} & \multicolumn{3}{|c|}{ Serum protein } & \multirow[b]{2}{*}{ Sugar } & \multirow{2}{*}{$\mathrm{HCO}_{2}^{-}$} & \multirow{2}{*}{ NPN } & \multicolumn{6}{|c|}{$\begin{array}{l}\text { Therapy between hrs. listed, with } \\
24 \text { hr. summary(1) }\end{array}$} & \\
\hline & & & & & & & Alb. & Glob. & Total & & & & N.S.(2) & $\begin{array}{l}\mathrm{M} / 6 \mathrm{Na} \\
\text { lactate }\end{array} \mid$ & $5 \%$ & cose in & Plasma & Insulin & \\
\hline & & $p H$ & meq. & meq. & meq. & meq. & $\begin{array}{c}\text { grams } \\
\text { per } \\
\text { cent }\end{array}$ & $\begin{array}{c}\text { grams } \\
\text { per } \\
\text { cent }\end{array}$ & $\begin{array}{c}\text { grams } \\
\text { per } \\
\text { cent }\end{array}$ & $\begin{array}{c}\text { mgm. } \\
\text { per } \\
\text { cent }\end{array}$ & meq. & $\begin{array}{c}\text { mgm. } \\
\text { per } \\
\text { cent }\end{array}$ & liters & liters & $N . S$ & $\underset{\mathrm{rS}}{\mathrm{H}}$ & liters & units (3) & \\
\hline 7 & & & & & & & & & & 770 & 10.5 & 100 & & & 1 & 1 & & 85 & \\
\hline 10 & & & 4.26 & 157 & 3.95 & 1.06 & & & 4.9 & & & 35 & & & & 1 & & 60 & \\
\hline 21 & & & 7.2 & 147 & 4.80 & 1.35 & & & 6.2 & & & & & & & & & 80 & \\
\hline 38 & & & 5.87 & 150 & 5.50 & 1.39 & 4.8 & 2.8 & 7.6 & 218 & & & & & & & & 70 & \\
\hline
\end{tabular}

No. 11, Patient J. S., White Female, 18, No. 866-215

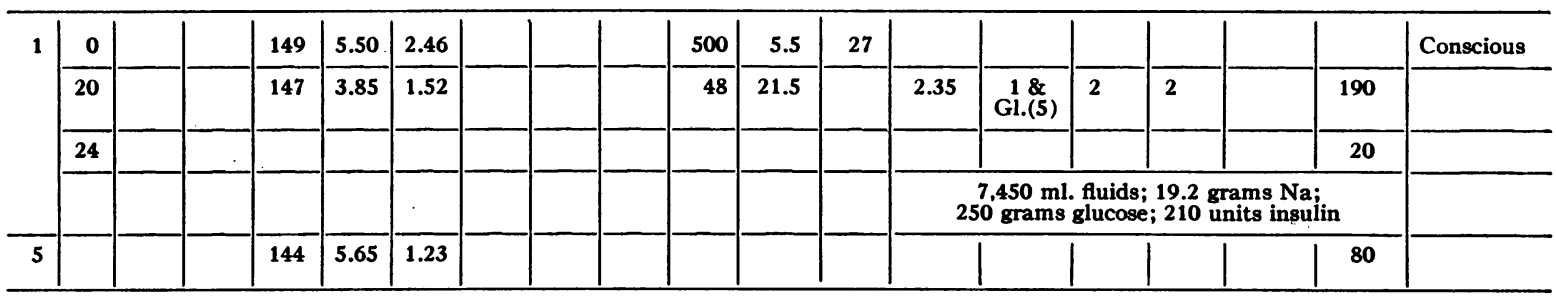

No. 12, Patient R. B., White Male, 40, No. 950-958

\begin{tabular}{|c|c|c|c|c|c|c|c|c|c|c|c|c|c|c|c|}
\hline 1 & 0 & & & & & & 1,092 & 5.5 & 95 & & & & & & $\begin{array}{l}\text { Comatose; } \\
\text { shock }\end{array}$ \\
\hline & 2 & 5.11 & 150 & 5.55 & 2.95 & 8.6 & 1,260 & $<4.5$ & & 2 & & & 0.25 & 180 & \\
\hline & 24 & & & & & & 310 & 20.5 & 40 & 4.7 & $\begin{array}{l}18 \\
\text { Gl.(5) }\end{array}$ & $\begin{array}{l}3 \\
1(7)\end{array}$ & 0.50 & 820 & \\
\hline & & & & & & & & & & \multicolumn{5}{|c|}{$\begin{array}{l}12,550 \mathrm{ml} \text {. fluids; } 27.5 \mathrm{grams} \mathrm{Na} \\
225 \text { grams glucose; } 1,000 \text { units insulin }\end{array}$} & \\
\hline 6 & & 4.98 & 149 & 4.45 & 1.39 & 6.7 & & & & & & & & 80 & \\
\hline 13 & & 5.54 & 141 & 4.65 & 1.23 & 5.5 & & & & & & & & 65 & \\
\hline
\end{tabular}

No. 13, Patient J. W., White Male, 13, No. 949-854

\begin{tabular}{|c|c|c|c|c|c|c|c|c|c|c|c|c|c|c|}
\hline \multirow[t]{4}{*}{1} & 0 & & 139 & 5.15 & 1.56 & 7.2 & 309 & $<4.5$ & 44 & & & & & Conscious \\
\hline & 19 & 3.52 & 144 & 5.45 & 1.23 & 6.1 & 175 & 14.0 & & 1 & 4 & 2 & 480 & \\
\hline & 24 & & & & & & & & & & & & 40 & \\
\hline & & & & & & & & & & \multicolumn{4}{|c|}{$\begin{array}{l}\text { 7,000 ml. fluids; } 17.7 \text { grams Na; } \\
300 \text { grams glucose; } 520 \text { units insulin }\end{array}$} & \\
\hline 6 & & 5.67 & 142 & 4.85 & 1.31 & 6.1 & & & & & & & 75 & \\
\hline
\end{tabular}

No. 14, Patient E. R., White Male, 40, No. 949-632

\begin{tabular}{|c|c|c|c|c|c|c|c|c|c|c|c|c|c|c|c|c|}
\hline \multirow[t]{4}{*}{1} & 1 & 10.34 & 143 & 5.05 & 2.75 & & 950 & $<4.5$ & 77 & & & & & & & \multirow{2}{*}{$\begin{array}{l}\text { Semi- } \\
\text { comatose; } \\
\text { shock }\end{array}$} \\
\hline & 20 & 3.82 & 157 & 4.30 & 0.98 & 5.4 & 326 & 19.5 & & $\begin{array}{l}3.5 \\
1(8)\end{array}$ & 1 & 1 & 1.2 & 1 & 480 & \\
\hline & 24 & & & & & & & & & & & 1 & 1 & & 40 & \\
\hline & & & & & & & & & & \multicolumn{6}{|c|}{$\begin{array}{l}10.700 \mathrm{ml} \text {. fluids; } 26.8 \text { grams Na; } \\
210 \text { grams glucose; } 520 \text { units insulin }\end{array}$} & \\
\hline 8 & & 5.08 & 143 & 4.40 & 1.48 & 5.9 & & & & & & & & & 100 & \\
\hline
\end{tabular}

(8) Normal (isotonic) saline given subcutaneously. 
3. Slightly low to normal sodium levels on entry, indicating with the hemoconcentration decreased total circulating sodium.

The relative constancy of the sodium concentrations during therapy, despite the use of large amounts of sodium intravenously10.5-27.5 grams.
4. The magnesium levels on entry were normal or elevated. There was a striking fall of concentration with the therapy of the first 24 hours. Values as low as $0.56-0.82$ M.eq. were obtained.

5. The majority of the calcium concentrations fell within the normal range, although four

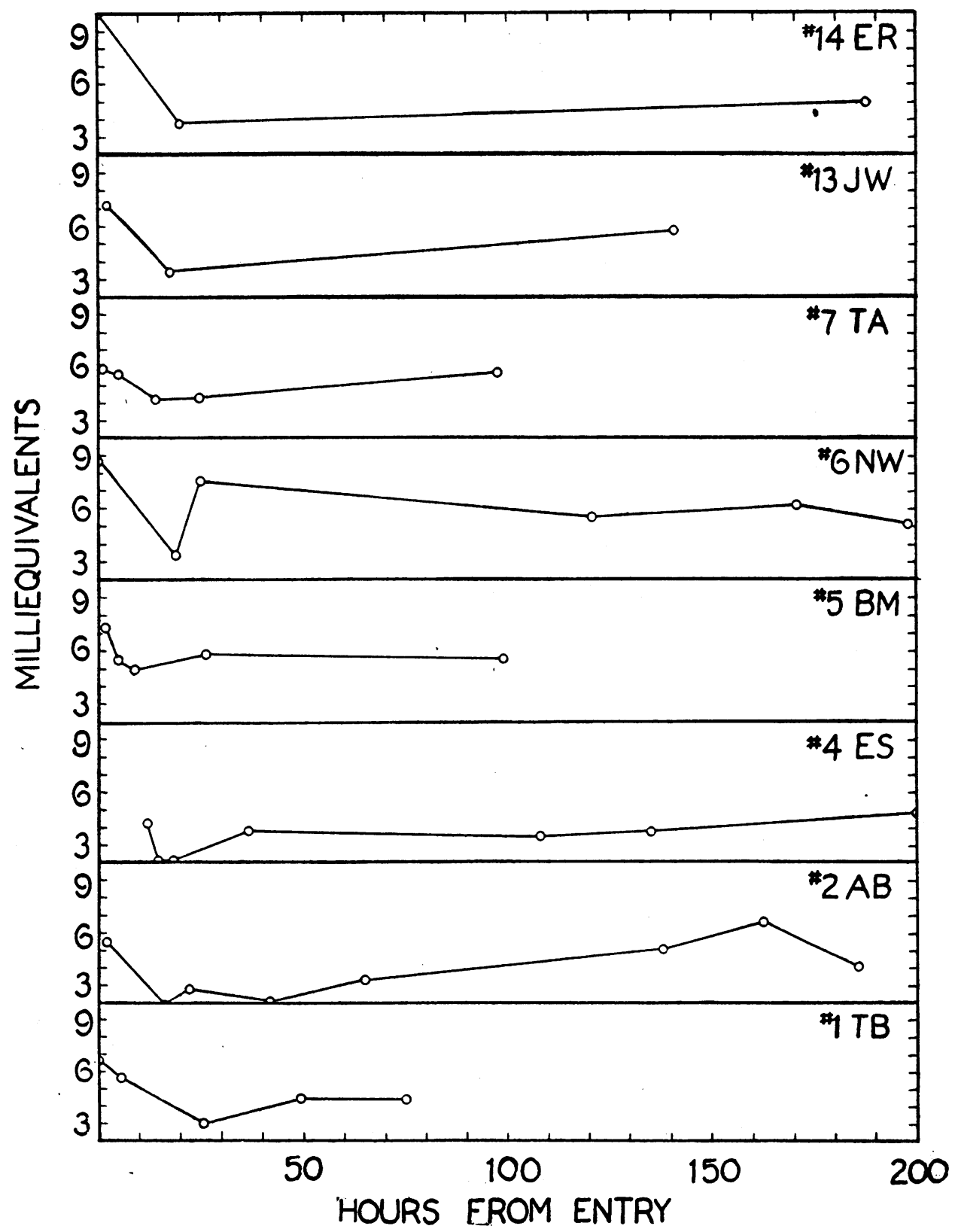

Fig. 1. Serum Potassium Levels During Therapy for Diabetic Acidosis

* Numbers of patients correspond to numbers in Table I. 


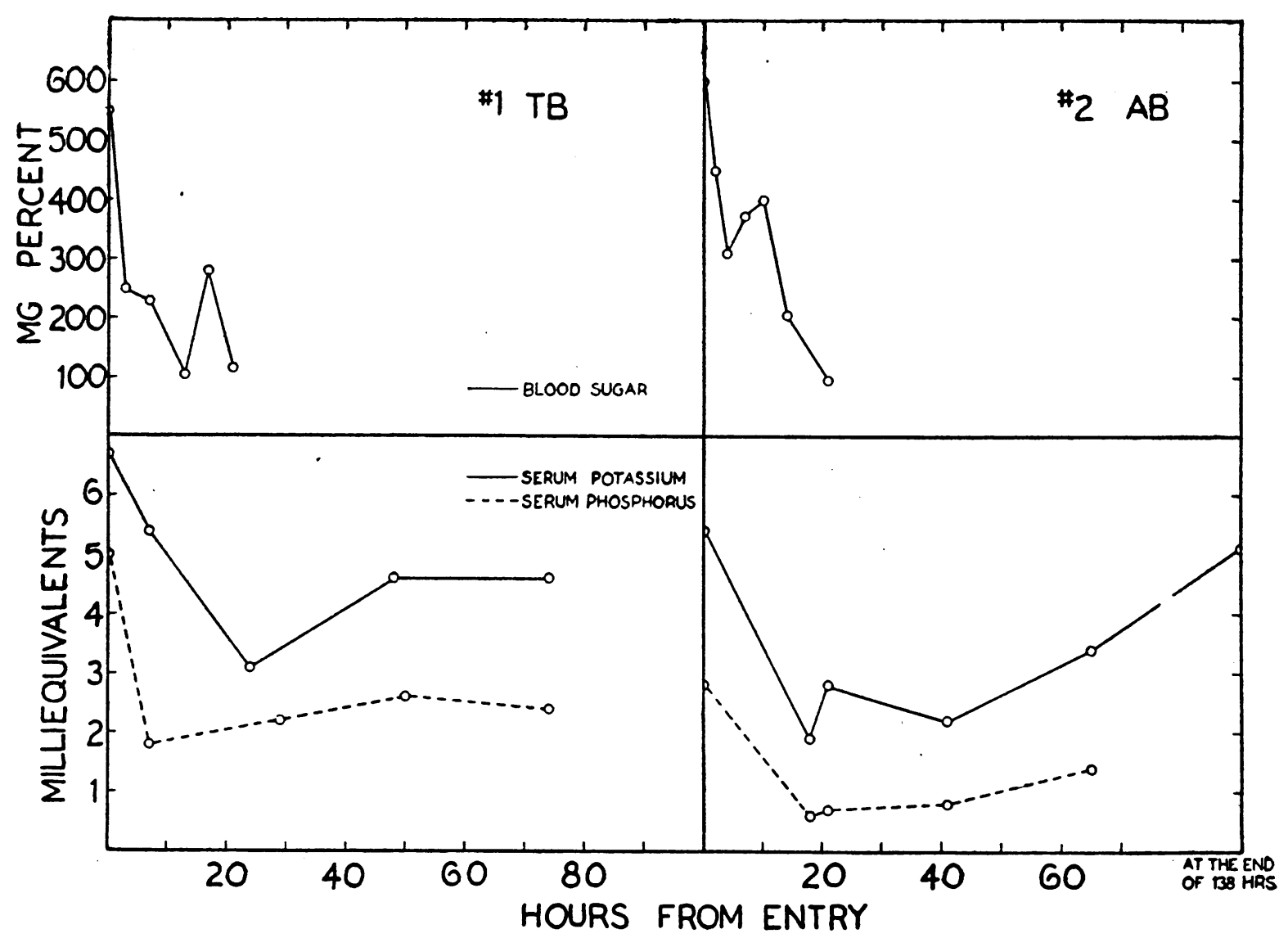

Fig. 2. Correlation of Changes in Serum Potassium, Phosphorus, and Blood Sugar Levels During Therapy for Diabetic Acidosis

* Numbers of patients correspond to numbers in Table I.

* Phosphorus calculated as $\mathrm{HPO}_{4}=$.

patients had levels under 4 M.eq. Small drops in concentration also occurred with therapy.

6. The wide range of blood sugar level on entry-285 to $1,092 \mathrm{mgm}$. per cent (5 patients had levels over $800 \mathrm{mgm}$. per cent), with carbon-dioxide combining power below $9^{\circ}$ M.eq. ( 7 patients had values below 4.5 M.eq.).

7. The wide range of insulin requirement in the first 24 hours-110 to 1,000 units.

8. The large amount of parenteral fluid-4 to 12 liters-given in the first 24 hours, with variation in amount of sodium from 10.5 grams to 27.5 grams, and glucose from 39 to 350 grams.

9. The clinical state varied from coma to consciousness, and 5 of the 14 patients were in shock.
The same general type of electrolyte changes occurred regardless of the amount of insulin, fluids, sodium, or glucose given in the first 24 hours, the rapidity of fall of the blood sugar, or the presence or absence of coma or shock.

More detailed analyses of the changes in the potassium levels are given in Figure 1. This figure demonstrates that the lowest point in potassium concentration usually occurred within the first 24 hours. Not enough serial determinations were made to determine the exact time of the lowest level, and this may vary from patient to patient, but it was usually between 12 and 24 hours. Within 2 to 3 days, the potassium concentrations had returned to normal levels, although in several patients this was delayed for several more days. Potassium concentrations as seen in Figure 1 were usually slightly elevated on entry in the majority of instances. There was no definite correlation 
between the rate of fall of the blood sugar, or the total amount of insulin and fluids given in the first 24 hours and the degree of lowering of the serum potassium. However, Figure 2 shows the close correlation in two patients (T. B., No. 1, Table I, and A. B. No. 2, Table I) between fall in blood sugar, inorganic phosphate and potassium levels.

Table II summarizes the range of potassium values found. It is seen that 6 patients ( 46 per cent) had low potassium values (under 4 M.eq.) and 8 patients had elevated levels (over $6 \mathrm{M}$.eq.). As it was not always possible to follow some of these patients during the first 24 hours, due to entry on holidays or at night, some abnormalities of potassium levels were doubtless missed.

TABLE II

Range of serum potassium levels in 13 patients

\begin{tabular}{|c|c|c|}
\hline Potassium level & $\underset{\text { patients* }}{\text { Number of }}$ & $\begin{array}{c}\text { Per cent o } \\
\text { patients }\end{array}$ \\
\hline $\begin{array}{l}\text { meq. } \\
1-3 \\
3-4\end{array}$ & $\begin{array}{l}2 \\
4\end{array}$ & $\begin{array}{c}\text { per cent } \\
15 \\
31\end{array}$ \\
\hline Summary of low values & 6 & 46 \\
\hline $\begin{array}{l}6-9 \\
9+\end{array}$ & $\begin{array}{l}7 \\
1\end{array}$ & $\begin{array}{r}55 \\
8\end{array}$ \\
\hline Summary of high values & 8 & 63 \\
\hline
\end{tabular}

* The same patient may be represented under both low and high levels.

Two of the patients complained spontaneously of marked muscle weakness after therapy. Both showed low serum potassium concentrations at the time.

While the majority of the calcium concentrations fell within the normal range, it was felt that with the fluctuations in $\mathrm{pH}$ and albumin and globulin levels the ionized calcium values might show more variation. The relationship between the calculated ionized calcium values and the total calcium concentrations is given in Table III. While the calculated ionized calcium levels tend to follow the fall and rise in total calcium concentrations this is not a constant relationship. This is illustrated by patient B. M. No. 2, Table III. With a total calcium concentration of $5.7 \mathrm{M}$.eq. the calculated ionized calcium was $2.25 \mathrm{M}$.eq. or 39 per cent of the total calcium. With a total
TABLE III

Relationship between total and calculated ionized calcium levels

\begin{tabular}{c|c|c|c}
\hline \hline Patient & Total calcium & $\begin{array}{c}\text { Calculated } \\
\text { ionized cal- } \\
\text { cium }\end{array}$ & $\begin{array}{c}\text { Calculated } \\
\text { ionized cal- } \\
\text { cium, per cent } \\
\text { of total } \\
\text { calcium }\end{array}$ \\
\hline E.S. No. 4* & meq. & meq. & per cent \\
& 5.20 & 2.45 & 47 \\
& 5.00 & 2.40 & 48 \\
& 5.15 & 2.30 & 45 \\
& 4.90 & 2.30 & 47 \\
B.M. No. 5* & 3.55 & 1.35 & 38 \\
& 4.95 & 2.05 & 41 \\
\hline T.B. No. 1* & 5.70 & 2.25 & 39 \\
& 4.40 & 2.05 & 47 \\
& 4.85 & 2.10 & 43 \\
\hline & 5.24 & 2.15 & 46 \\
& 4.64 & 2.05 & 44 \\
& 4.80 & 2.20 & 46 \\
& 4.68 & 2.25 & 48 \\
& 4.98 & 2.25 & 45 \\
\hline
\end{tabular}

* Table I.

calcium of 4.4 M.eq. the ionized value was 2.05 M.eq. or 47 per cent of the total.

Magnesium concentrations fell markedly during therapy, particularly during the first 24 hours, although in some instances the maximum fall occurred later. Even after several days, the magnesium concentrations had not returned to the normal level in the majority of the patients. The range of serum magnesium levels is given in Table IV. Forty-one of the 67 determinations (61 per cent) in the 14 patients were below normal, while 11 (16 per cent) were elevated. Five patients showed very low levels-under 1 M.eq.

Correlation between the state of consciousness and the level of magnesium at entrance was found,

TABLE IV

Range of serum magnesium levels in 14 patients

\begin{tabular}{l|c|c|c}
\hline \hline & $\begin{array}{c}\text { Magnesium } \\
\text { levels }\end{array}$ & $\begin{array}{c}\text { Number of } \\
\text { determina- } \\
\text { tions at level } \\
\text { indicated }\end{array}$ & $\begin{array}{c}\text { Number of } \\
\text { patients(1) }\end{array}$ \\
\hline Very low & meq. & 5 & \\
Low & $0.56-1.00$ & 5 & 5 \\
Normal(2) & $1.00-1.50$ & 36 & 13 \\
Slightly elevated & $1.50-1.92$ & 15 & 11 \\
High & $1.92-2.30$ & 4 & 3 \\
\hline
\end{tabular}

(1) The same patient may be represented under each level due to changes in concentration with therapy.

(2) The normal range for the method used -1.50 to 1.92 milliequivalents. 
although none of the values obtained was abnormally high. Three of the patients with magnesium levels over 2.5 M.eq. were in deep coma; one was stuporous. All eight patients with magnesium levels under 2.5 M.eq. on entry were conscious. There was no correlation between the level of magnesium at entrance and the presence or absence of hemoconcentration.

\section{DISCUSSION}

Some of the changes in the potassium, calcium, and magnesium levels are undoubtedly due to hemoconcentration or dilution, although study of Table I will show that many of the changes bear no direct relationship to this factor. The concentration of electrolytes at any one moment, regardless of total circulating amount, conditions many of their physiologic functions. This is well attested by the striking changes in the $T$ waves in the electrocardiogram with changing levels of serum potassium (18). It has also been demonstrated that the total circulating amount of any electrolyte, particularly sodium, may be important, as seen in the clinical improvement in patients with Addison's disease after salt therapy, even before the serum sodium concentrations return to normal (19). In general the importance of potassium, calcium, and magnesium in many biologic functions has been adequately reviewed $(20,21$, 22).

The marked drop in serum potassium is the most striking of the electrolyte changes noted and has not been stressed previously. The level of 1.9 M.eq. found in one of our patients is, to our knowledge, the lowest level mentioned in a diabetic. Very low levels of serum potassium have been reported in several conditions: sprue-1.1. M.eq. (23) ; familial periodic paralysis-1.3 M.eq. (24) ; Addison's disease with therapy-2.9 M.eq. (25).

In diabetes there are several factors relevant to the problem which are known to effect the serum potassium levels. Potassium moves in or out of the cell fairly closely with phosphorus and nitrogen during periods of either tissue catabolism or anabolism $(26,27)$. With periods of excess tissue breakdown, there is increased urinary excretion of potassium; and, conversely, during protein storage there is decreased urinary excretion of potassium. Administration of certain hormones, or their lack due to disease, can cause such shifts in potassium and nitrogen. Testosterone (28) causes protein anabolism and decreased potassium excretion in the urine, while desoxycorticosterone acetate (19) causes increased urinary excretion of potassium, and decreased extra- and intra-cellular potassium concentrations. Lack of insulin is known to lead to tissue breakdown and a negative nitrogen balance with loss of large amounts of potassium in the urine (5). Administration of insulin leads to a positive nitrogen balance and decreased urinary potassium excretion (5). As the blood levels of potassium and urinary excretion of potassium (and phosphorus) decrease after insulin, it has been suggested (28) that' there is an increased intracellular level of potassium and phosphorus, possibly without increase in muscle mass. This possibility must remain a suggestion, however, until determinations of intracellular levels of potassium are made in man following insulin therapy and until the amount which may shift into the liver can be determined. In the normal individual, as well as the diabetic, insulin is known to decrease the serum potassium levels $(4,29,30)$. The exact mechanism of this action of insulin on serum potassium is not known, but it has been suggested that it is correlated with shifts of glucose and phosphate into the cell, for formation of a potassium hexosephosphate (see Figure 2), or into the liver in glycogenesis $(4,29,31,32)$.

Another condition that may possibly decrease serum potassium levels in severe diabetic acidosis is the use of large amounts of intravenous saline. Administration of large volumes of fluid parenterally (isotonic) (33) causes loss of some potassium in the urine with the loss of large amounts of sodium. Whether this factor is counterbalanced in diabetics by the effect of insulin in decreasing urinary potassium excretion has not been studied.

Clinically the feature that impressed us as related to the low levels of serum potassium was the marked muscle weakness exhibited by several patients. One of these patients, following a minor insulin reaction, which was treated promptly, showed striking generalized muscle weakness and lethargy. In many respects she resembled the picture seen in familial periodic paralysis. All pa- 
tients showed clinical improvement in muscle strength with rise in serum potassium levels. The relationship between muscle weakness, intracellular and extracellular potassium levels is still not settled. Following the use of testosterone, the serum potassium may drop to very low levels, with increased or normal intracellular potassium, and no associated muscle weakness (28). Desoxycorticosterone acetate therapy, if excessive, causes marked loss of potassium, and decreased intracellular potassium concentrations, and is associated with marked muscle weakness (25). In familial periodic paralysis (24) and diabetes with low serum potassium levels there is also marked muscle weakness. The drop in serum potassium concentrations, with decreased urinary excretion during insulin therapy, may be theoretically associated with either increased or decreased intracellular levels, depending on whether the shift is predominantly into the cells, or into the liver in intermediary carbohydrate metabolism and glycogen formation. That there are other factors involved in muscle strength beside intracellular potassium levels has been demonstrated experimentally in rats, who despite very low levels of muscle potassium, were still able to swim (34).

On entry, many of the patients showed elevated levels of potassium. Most of this rise in concentration can be explained on the basis of hemoconcentration. Another factor is decreased renal function secondary to shock which may occur in diabetic -acidosis.

The calcium concentrations were maintained at normal or slightly low normal levels in most instances, despite the fact that in diabetic acidosis there is increased urinary excretion of calcium (5). Total circulating calcium is presumably depleted. As many diabetics show marked osteoporosis, periods of negative nitrogen balance and acidosis may be pathogenic factors. The lack of constant correlation between total calcium concentration and percentage ionized fraction is important, as the ionized fraction determines many of the physiologic effects of calcium, such as the length of the electrical systole of the heart. This suggests that both values should be determined.

The mechanism of the marked drop in magnesium concentrations during insulin therapy has not been studied. Possibilities include changes in urinary excretion or use in carbohydrate metabolism with insulin therapy. It should be noted, however, that the amount of magnesium necessary for coenzyme action in the phosphorylation of glucose would appear to be too small to account for the marked changes observed. It is interesting, but not conclusive, that there was some correlation in our series between levels of consciousness and the magnesium concentrations at entry. However, at levels similar to those found in our comatose patients, many individuals appear to have no effects or clinical symptoms. Also, many factors presumably contribute to the state of coma, and no one chemical factor is entirely responsible.

The therapeutic implications of these findings are important. The occurrence of low potassium levels after therapy in 46 per cent of the patients, and very low magnesium levels in 36 per cent of the patients, suggests that these patients should receive potassium and magnesium salts as an adjunct to other therapy. The warning should be given, however, that a diabetic patient-in shock, with decreased renal function, should not receive potassium therapy because of the danger of producing dangerously high blood levels (35). This is true also for magnesium. The presumed decrease in total circulating calcium and occasional decreases in the percentage ionized fraction suggest that these salts should be beneficial, too.

\section{- SUMMARY}

The results of determinations of potassium, magnesium, and calcium levels in 14 patients in severe diabetic acidosis are given.

Forty-six per cent of the patients showed a marked fall in serum potassium levels during therapy. In several patients this was associated with marked muscle weakness. It is suggested that this fall may be related to the effect of insulin on nitrogen storage and urinary excretion of potassium, and the carbohydrate cycle with passage of glucose, phosphorus, and potassium into the muscle cell, or into the liver in glycogen formation.

There was no constant correlation between total calcium concentrations and the ionized fraction. While the concentrations of calcium on entry were usually within the normal range, total circulating amount was presumably decreased, in view of the 
hemoconcentration present. This may be a factor in osteoporosis.

There was a marked fall in serum magnesium concentrations in 36 per cent of the patients during therapy, and the levels returned very slowly to the normal range. No explanation can be given for this change. Elevated magnesium levels may play a rôle in the production of coma.

The therapeutic implications of these findings are discussed.

\section{ACKNOWLEDGMENTS}

Appreciation is expressed to Dr. D. G. Simonsen and Dr. John W. Mehl for help on all aspects of the chemical problems involved in this study.

\section{BIBLIOGRAPHY}

1. Hartmann, Alexis F., and Darrow, Dan C., Chemical changes occurring in the body as the result of certain diseases. III. The composition of the plasma in severe diabetic acidosis and the changes taking place during recovery. J. Clin. Invest., 1928, 6, 257.

2. Gamble, J. L., Chemical anatomy, physiology, and pathology of extracellular fluid. Department of Pediatrics, The Harvard Medical School, 1939.

3. Peters, John P., Kydd, David M., Eisenman, Anna J., and Hald, Pauline M., The nature of diabetic acidosis. J. Clin. Invest., 1933, 12, 377.

4. Harrop, George A., Jr., and Benedict, Ethel M., The participation of inorganic substances in carbohydrate metabolism. J. Biol. Chem., 1924, 59, 683.

5. Atchley, Dana W., Loeb, Robert F., Richards, Dickinson, W., Jr., Benedict, Ethel M., and Driscoll, Mary E., On diabetic acidosis. A detailed study of electrolyte balances following the withdrawal and reestablishment of insulin therapy. J. Clin. Invest., 1933, 12, 297.

6. Barber, H. H., and Kolthoff, I. M., A specific reagent for the rapid gravimetric determination of sodium. J. Am. Chem. Soc., 1928, 50, 1625.

7. Kramer, B., and Tisdall, F. F., A clinical method for the quantitative determination of potassium in small amounts of serum. J. Biol. Chem., 1921, 46, 339.

8. Clark, E. P., and Collip, J. B., A study of the Tisdall method for the determination of blood serum calcium with a suggested modification. J. Biol. Chem., 1925, 63, 461.

9. Simonsen, D. G., Westover, Leola, and Wertman, Maxine. (In press.)

10. Simonsen, Daisy G., Wertman, Maxine, Westover, Leola M., and Mehl, John W., The determination of serum phosphate by the molybdivanadate method. J. Biol. Chem., 1946, 166, 747.

11. Kingsley, G. R., The determination of serum total protein, albumin, and globulin by the biuret reaction. J. Biol. Chem., 1939, 131, 197.
Ibid., A rapid method for the separation of serum albumin and globulin. J. Biol. Chem., 1940, 133, 731.

Ibid., The direct biuret method for the determination of serum proteins as applied to photoelectric and visual colorimetry. J. Lab., and Clin. Med., 1941$2,27,840$.

12. Van Slyke, Donald D., Stillman, Edgar, and Cullen, Glenn, Studies of acidosis. XIII. Method for titrating the bicarbonate content of the plasma. J. Biol. Chem., 1919, 38, 167.

13. Peters, John P., and Van Slyke, Donald D., Quantitative Clinical Chemistry. The Williams and Wilkins Company, Baltimore, 1932, 11, 527.

14. Benedict, S. R., The estimation of sugar in blood and normal urine. J. Biol. Chem., 1926, 68, 759.

15. Weir, E. G., and Hastings, A. B., The ionization constants of calcium proteinate determined by the solubility of calcium carbonate. J. Biol. Chem., 1936, 114, 397.

16. McLean, Franklin C., and Hastings, A. B., The state of calcium in the fluids of the body. I. The conditions affecting the ionization of calcium. J. Biol. Chem., 1935, 108, 285.

17. Van Slyke, Donald D., Hastings, A. B., Hiller, Alma, and Sendroy, Julius, Jr., Studies of gas and electrolyte equilibria in blood. XIV. The amounts of alkali bound by serum albumin and globulin. $\mathrm{J}$. Biol. Chem., 1928, 79, 769.

18. Martin, Helen Eastman, and Wertman, Maxine, Correlation of the electrocariographic changes in diabetic acidosis with the electrolyte changes. To be published.

19. Thorn, George W., Howard, R. Palmer, and Emerson, Kendall, Jr., Treatment of Addison's disease with desoxycorticosterone acetate, a synthetic adrenal cortical hormone. J. Clin. Invest., 1939, 18, 449.

20. Fenn, W. O., The role of potassium in physiological processes. Physiol. Rev., 1940, 20, 377.

21. Schmidt, Carl L., and Greenberg, David M., Occurrence, transport, and regulation of calcium, mag nesium, phosphorus in animal organism. Physiol. Rev., 1935, 15, 297.

22. Darrow, Daniel C., Body-fluid physiology: The relation of tissue composition to problems of water and electrolyte balance. New Eng. J. Med., 1945, 233, 91.

23. Harrison, Harold E., Tompsett, Ralph R., and Barr, David P., The serum potassium in two cases of sprue. Proc. Soc. Exper. Biol. and Med., 1943, 54, 314.

24. Allott, E. N., and McArdle, B., Further observations on familial periodic paralysis. Clin. Sc., 1938, 3, 229.

25. Ferrebee, Joseph W., Ragan, Charles, Atchley, Dana W., and Loeb, Robert F., Desoxycorticosterone esters; certain effects in the treatment of Addison's disease. J. A. M. A., 1939, 113, 1725. 
26. Howard, J. E., and Bigham, R. S., Relation of potassium to nitrogen during anabolism and catabolism of protoplasm-Page 7, Conference on Metabolic Aspects of Convalescence, Transactions of Eleventh Meeting, 1945, Massachusetts General Hospital, Boston, Mass.

27. Albright, F., Reifenstein, E. C., Jr., and Forbes, A: P., Does potassium move with nitrogen?-Page 25, Conference on Metabolic Aspects of Convalescence, Transactions of Eleventh Meeting, 1945, Massachusetts General Hospital, Boston, Mass.

28. Butler, Allen M., Talbot, Nathan B., and MacLachlan, E. A., Effect of testosterone therapy on concentration of potassium in serum. Proc. Soc., Exper. Biol. and Med., 1942, 51, 378.

29. Briggs, A. P., Koechig, Irene, Doisy, Edward A., and Weber, Clarence J., Some changes in the composition of blood due to the injection of insulin. J. Biol. Chem., 1924, 58, 72.
30. Clegg, J. L., Serum potassium and serum calcium in insulin shock therapy. 'Lancet, 1939, 236, 871.

31. Fenn, W. O., The deposition of potassium and phosphate with glycogen in rat livers. J. Biol. Chem., 1938, 128, 297.

32. Cori, C. F., Phosphorylation of glycogen and glucose. Biol. Symposia, 1941, 5, 131.

33. Stewart, John D., and Rourke, G. Margaret, The effects of large intravenous infusions on body fluid. J. Clin. Invest., 1942, 21, 197.

34. Miller, H. C., and Darrow, D. C., Relation of serum and muscle electrolyte, particularly potassium, to voluntary exercise. Am. J. Physiol., 1941, 132, 801.

35. Winkler, Alexander W., Hoff, H. E., and Smith, Paul $\mathrm{K}$., Electrocardiographic changes and concentration of potassium in serum following intravenous injection of potassium chloride. Am. J. Physiol., 1938, 124, 478. 